\title{
洗浄剤と鿁飲・誤用事故（その 2)
}

\section{一米国せっけん・洗剤工業会技術報告書一}

武井 玲子・佐道 房枝 - 大場 健吉

ライオン株式会社生物科学研究所（广256 小田原市田島 202)

Cleaning Products and Their Accidental Exposure (Part 2)

(Technical Report by The Soap and Detergent Association)

Reiko TAKEI, Fusae SADŌ, and Kenkichi ŌBA

Biological Science Laboratories, Lion Corporation

(202, Tajima, Odawara-shi, Kanagawa-ken, ₹256)

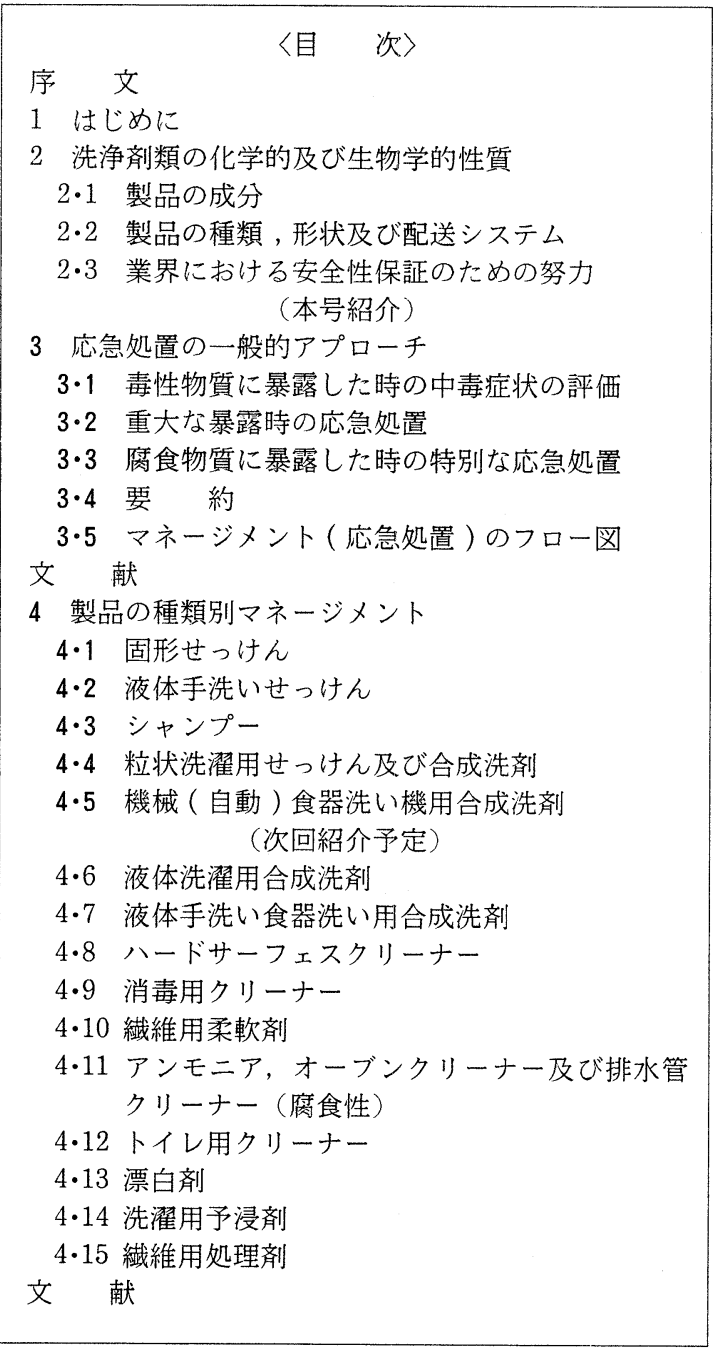

\section{3 応急処置の一般的アプローチ}

A.R. Temple, M.D. and D.G. Spoerke, M.S., R. $\mathrm{Ph}$.

本章では, 洗浄剤の誤飲・誤用暴露事故に対する一般 的な応急処置法について述べる。誤飲・誤用した製品と その成分については正確には必ずしもわかっていない。 従って, 最小から致死的な毒性という広範囲の中毒事故 に対する一般的なアプローチに基づいて，患者を診断し 応急処置を行うことがしばしば必要となる。参考までに, 既に用意されているアプローチの例として応急処置つ ロー図を本章で紹介する。何人かの研究者が一般的な応 急処置法を公表しているので，これらを参考にして本 章で述べている内容をより一層充実されることを勧め $3^{1) \cdot 2)}$ 。

\section{.3.1 毒性物質に暴露した時の中毒症状の評価}

まず最初の段階は, 患者の現在の健康状態を診断する ことである。中枢神経系の抑制，おう(嘔)吐,けいれん (痙攣), 下痢, 眼の痛み, 不安定な生存崟候, 呼吸困 難のような明らかに苦痛を示す徴候が見られたり，また 生命を脅かす徵候や症状が認められた場合は，患者を可 及的速やかに安定な状態に維持することである。

安定している患者を診断する時は, まず正確な病歷之 暴露を評価する情報を聞き出す。患者が医者の診断を希 望しているのかまたは電話によるアドバイスを求めてい るのかを確認する。正確な病歴には次の内容が含まれる。 (1)患者の現在の状態＼cjkstart既述のように, これは暴露の程 度を評価するための最初の問診である。

(2)製品情報正確な製品の名前がわからない場合，一 般的な種類は何か? その製品が洗濯用合成洗剂, 排水管 クリーナー, 化粧せっけんなどであるか? 暴露が実際 
に起こったか否かを確認する。

(3)摂取量 患者の衣類, 皮膚, 口のまわりにこぼれた 物理的形跡及び製品の大きさや濃度から患者の摂取量を 推定する。

(4)捸取後の経過時間同様なタイプの暴露でも暴露後 $10 \mathrm{~min}, 4 \mathrm{~h}, 2 \mathrm{~d}$ 後では異なった処置が必要となる。 (5)患者特有の情報電話で問い合わせを受けた場合, 患者の電話番号, かかりつけの医者, 最も近い医療機関 を聞くこと。患者の過去の病歴は, 患者の素因について 意思決定する時の参考になる。

(6)暴露経路 申し立てた経路以外に暴露されていない かどうかを確認する。例えば，最初は単独の経口暴露で あったとしても, 皮膚, 鼻, 耳からの暴露経路が加わる 可能性もある。

(7)その他複数物質暴露の可能性非腐食性のせっけん や合成洗剂の誤飲・誤用暴露の多くの事例では, 重症で あったり致命的な症状は見られない。しかし，患者がそ の他の物質も追加して一緒に摂取していたならば，結果 は全く異なる。

\section{$3 \cdot 2$ 重大な暴露時の応急処置}

患者に症状が見られたり重篤な合併症が併発する可能 性が考えられる場合は，患者を医療機関で受診させ次に 述べる応急処置法を考慮する。

\section{$3 \cdot 2 \cdot 1$ 一次救命処置}

一次救命処置とは, 基本的な身体の機能である呼吸・ 循環系や神経系の機能維持に焦点を合わせた処置であ る。脈拍数, 血圧, 体温, 水和状態, 呼吸状態及び中枢 神経系の状態を検査する。救命処置には, 人工呼吸, 外 部心マッサージ, 輸液や薬品の静注投与及び酸素吸入が 含まれる。

\section{$3 \cdot 2 \cdot 2$ 研究所の役割}

患者が安定したらすぐに, 分析用試料を採取する。せっ けんや合成洗剂を単独で摂取している場合は，毒性学上 の薬物検查は有用でない。しかし，複数物質を同時に摂 取していたり，またはその疑いがある場合及びせっけん や合成洗剂を摂取した症状と相関していない時は，血液 や尿, 吸引された胃内容物の分析は有用となる。毒性学 的分析結果から, 家庭用品の暴露を確認したり否定した りすることは難しい。多量の嘔吐や下痢が認められる場 合は, 電解質の状態を検査する。腐食性または強い刺激 性の物質が眼に入った時は，眼検査を追加する。

\section{$3 \cdot 2 \cdot 3$ 暴露/吸収の最小化}

〈吸入〉

患者を暴露された場所からすぐに移動させる。呼吸状 態を診察し，呼吸維持や酸素吸入を考慮する。

〈眼〉

眼に入った場合は,できるだけ速やかに体温に近い水 (ぬるま湯) で洗浄する。特別な洗浄液で洗浄する必要
はない。腐食物質の場合は, 眼の損傷が急激に起こる。 洗浄は少なくとも $15 \mathrm{~min}$ は続ける。眼自身と共にまぶ た(瞼)の下の部分も注意して洗浄する。せっけんや合成 洗剤の中には，不溶性の粒状物質を配合しているものも あるので眼を擦ることは避ける。

〈皮膚〉

接触部位すべてを大量の水で洗う。暴露されたすべて の衣類は脱がせ，污れを洗浄，除去する。

〈摂取〉

（1）希 瀵

腐食性もしくは刺激性の物質を誤摂取した場合は，希 採する必要がある。水や牛乳のいずれも希瑶剂として適 切である。希釈剂の投与量は, 患者に過剩負荷とならな いようにまた一緒に投与された錠剤やカプセルを溶解し たり吸収促進しないようにコントロールする。大量の希 釈液は胃内での滞留時間を増加させたり，錠剤やカプセ ルを小腸へ移動させることになる。大人の場合, 120～1 $50 \mathrm{~mL}$ の牛乳や水で希釈し, 子供の場合は $15 \mathrm{~mL} / \mathrm{kg}$ を越えてはならない。

\section{（2）胃からの摂取物質の除去}

せっけんや合成洗剂を誤摂取した事例の中には，胃内 容物の吸引や胃洗浄が必要となる事例もある。洗浄剤の ある製品はその毒性は低く，一方，その他の製品は催吐 作用や下痢が認められるので, 吸引処置を追加する必要 はない。全身的な影響や複数物質の㠌取のために胃の中 を空にする必要がある時は, 主に患者の状態や暴露後の 経過時間から判断して嘔吐もしくは胃洗浄のいずれかの 処置を選択する。

嘔吐は，吐根シロップ（液体抽出能の無いもの）を用 いて誘発させる。食塩水, 皿洗いせっけん，硫酸銅やア ポモルヒネのようなその他の催吐剂は, 使いにくさや副 作用または効果が不充分であるために，使用されること はまれである。吐根シロップの投与量は，大人もしく は 90〜100 ポンド（約 40〜 45 kg）以上の子供の場合は $30 \mathrm{~mL}$, 生後 6〜12 か月の子供は 5〜10 mL, 1〜12 才の 子供は $15 \mathrm{~mL}$ である。吐根シロップ投与の次に水を, 大人は 6〜8オン人（約 180～240 mL),子供は 4〜6オ ンス（約 120１80 mL）の割合で与える。嘔吐は投与 直後に見られることもあるが, 通常は若干遅れる。最初 の投与で嘔吐が起こらなければ, 20〜30 min 以内に再 度吐根シロップを投与する。腐食物質は嘔吐が禁忌であ る物質の一つであることをおばえておくべきである。そ の他の禁忌は, こん(昏)睡状態で催吐反射が亦失してい る患者（嘔吐が危険となる患者）や治療中発作が起こる 可能性のある患者に対して嘔吐させることである。胃の 中を空にする処置は, 摂取直後に行わなければ効果がな い。まれにではあるが, 嘔吐の合併症として食道のマロ リー・ワイス症候群, 胃内容物の吸引, 年輩の患者に 
見られる脳内出血, 綐隔気しゅ(腫), 及び後腹膜性鼓ちょ う(脹)が発症することもある ${ }^{3), 4), 5), 6) 。 ~}$

胃洗浄は, 通過可能な大きさのチューブを用いて実施 する。内腔の広い胃チューブの使用が望ましい7).8)。 患者を左側が(臥)位に寝かせ頭を低くした状態を保って 洗浄することで, 気道を守るための気管内挿管は必要な くなる ${ }^{9}$ 。洗浄液を注入する前に胃内容物を吸引する。 胃洗浄は, 5 才以上の子供と大人に対して，1回の洗浄は 150 200 mL の妨湯もしくは生理食塩水で, 5 才 以下の子供は $50 \sim 100 \mathrm{~mL}$ の生理食塩水で行う。吸引 した洗浄水が透明になるまで, 胃洗浄を継続する。体液 上電解質のバランスが不均衡になるのを避けるために, 吸引する液量と投与する液量とはほぼ同量とする。

活性炭は, 種々の医薬品, 化学物質や毒物を吸着する 物質亡して有用である。活性炭のせっけんや合成洗剂誤 摂取時の応急処置としての有用性は, 活性炭吸入の危険 性, 投与の難しさ, 熱傷の危険性及びソルビトールを混 合した活性炭配合製品による激しい下痢の危険性の観点 から評価するのが望ましい。吸着すべき複数物質を摂取 した場合や全身影響のある物質を配合しているせっけん や合成洗剂の 2,3 の事例では，その使用を考慮する。家 庭用洗浄剂を摂取した多くの場合, 活性炭の使用は疑問 である。

下剂。家庭用洗浄剂には胃腸管粘膜を刺激する成分が 配合されているので, 充分量を攝取すると下疡が起こる。 したがって，家庭用合成洗剤を単独に摂取した場合は， 胃腸管を更に刺激する必要はない。その他の物質を併用 摂取している場合は，下剤投与を考える。下痢が続く之 体液之電解質のバランスが乱れるので, 患者の水和状態 を診断する。一般的には食塩水の下剤が最も安全である と考えられているが, 活性炭/ソルビトール混合物は混 合して投与する点でより好ましい。

\section{（3）解毒剤}

家庭用洗浄剂暴露時に使用できる特別な解毒剂はな い。解毒剤を投与すると洗浄剤と併用摂取されることに なるので，それが適切であるから゙うかを考慮する。

（4）吸収された物質の除去

これらの方法には，主に利尿（例えば，アルクリ性利 尿, 強制利尿)及び透析 (例えば, 腹膜透析, 血液透析, 樹脂による血液灌流）の 2 方法がある。家庭用洗浄剂に は, 全身的に吸収されて重篤な臨床症状を示す物質が配 合されていることはまれであり，また透析や利尿のいず れかの処置を必要亡する症状もめったに見られない。こ れらの方法は, 一般的には家庭用品の応急処置ししては 不必要であったりまた無効と考えられる。

（5）その他の支持療法

以下に述べる処置法は, 重篤な症状の場合必要となる。 用いられる救急医療処置はその他の分野の場合上同様で
ある。

血圧低下は, 洗浄剤の暴露ではまれな症状である。最 初に行うことは体液の交換と患者をトレンデレンブルグ 体位に維持することである。これらの処置を行っても回 復しない場合は, ドーパミン $(2 \sim 5 \mu \mathrm{g} / \mathrm{kg} / \mathrm{min})$ もし くはノルエピネフリン $(2 \sim 4 \mu \mathrm{g} / \mathrm{min})$ を投与する。

嘔吐や下痢が激しいと脱水症になる可能性がある。希 釈した電解質溶液による体液交換は, 子供の場合 75 $\mathrm{mL} / \mathrm{kg}$, 大人の場合 $100 \mathrm{~mL} / \mathrm{kg}$ の割合で脱水症が回復 するまで行う。

中枢神経抑制作用は, 家庭用品の暴露ではめったに見 られない合併症である。応急処置は, 呼吸器及び心臓血 管系の維持を慎重に行うことである ${ }^{10)}$ 。

中枢神経興奮作用及び急発作もまた通常は観察されな い副作用である。しかし，ある種の第四級アンモ二ウム 化合物を摂取した時に起こる可能性がある。急発作の場 合は, ジアゼパム 5〜10 mg 2〜3 min 以上かけて静 注投与する。継続投与は最大 $30 \mathrm{mg}$ まで必要に応じて 10〜15 min ごとに行う。生後 1 か月以上 5 才未満の子 供には最大 $5 \mathrm{mg}$ まで, 5 才以上の子供は最大 $10 \mathrm{mg}$ まで,それぞれ $0.2 \sim 0.4 \mathrm{mg} / \mathrm{kg}$ の割合で投与する。フェ ニトインもしくはフェノバルビタールのようなその他の 抗痤攣薬も使用できる。

脳浮腫は, 液体の過剰負荷もしくは低酸素症となった 患者に発症する可能性がある。静注投与マンニトールも しくはコルチコステロイドと尿素療法が応急処置法とし て有効である。

\section{$3 \cdot 3$ 腐食物質に暴露した時の特別な応急処置}

ある種の家庭用品は, 腐食作用により熱傷を起こす。 ある物質が刺激性あるいは腐食性があるかどうかは, $\mathrm{pH}$ ，アルカリ度，濃度及び製品中に配合されているそ の他の緩衝剂など多くの要因に基づいて判断される。中 毒コントロールセンターや企業の医学部門からのデー夕 は, 製品の腐食性を評価する時にしばしば有用となる。

腐食作用による熱傷の可能性があると診断された場合 は, 食道鏡検査もしくは内視鏡検査で熱傷の部位, 範囲, 深さを診断する。熱傷が認められるすべての患者に， こう(腔)内に明らかな症状が見られるとは必ずしも限ら ない。口腔内に熱傷が見られない場合も，食道に熱傷が 生じている可能性がある。ある研究報告によると, ぜん (喘) 音, 嘔吐及び流えん(涎)の 3 症状のうち 2 つ以上の 症状が認められる患者の $50 \%$ には,これらの 1 症状が 見られたりまたは何も見られないグループで内視鏡検査 でも陰性であった患者と比較した時, 重篤な食道損傷を 認めたことが示されている11)。

\section{$3 \cdot 3 \cdot 1$ 食道鏡検査}

腐食物質を摂取したために明確な症状が見られたり喘 音, えん(嚥)下困難, 流涎が認められる場合, 食道鏡検 
査を最初の $24 \sim 48 \mathrm{~h}$ 以内に行う。損傷による壊死がみ られる間は, 食道鏡検査は行うべきでない。もし熱傷が 見られる場合, 後になって行われる拡張療法の際に, 誤つ た通路をつくってしまうのを避けるために，道標となる 糸状のものをあらかじめ胃の内に留めておくことが必要 となる。ステロイドは 3 週間にわたり投与できるが, 順 次少なくする。ステロイドが効果的であったという臨床 報告はほとんどないが, 動物実験では若干の効果が示唆 されている。3度の熱傷または周辺部の深い熱傷に対し ては, コルチコステロイドの投与も処置法のひとつであ る。プレドニゾン $1 \sim 2 \mathrm{mg} / \mathrm{kg}$ 及びデキサメタゾン 1.2 $\mathrm{mg} / \mathrm{kg} / \mathrm{d}$ が適切な投与量の例である。拡張, 結腸のふ ん(吻) 合, 胃ゾンデ, 更に $\beta$-アミノプロピオニトリル のようなその他の治療は, 本論の範囲外の処置である。

\section{$3 \cdot 3 \cdot 2$ 眼への暴露}

眼の熱傷を適切に診断するためには, 暴露後 $48 \sim 72 \mathrm{~h}$ 以内に検査する必要がある。熱傷の程度を評価する基本 は, 角膜の混濁化及び周辺の白化の程度を診断すること である。後方療着や毛様体の痙縮の発症防止のために, 1 日に 2 回の割合で $1 \%$ アトロピンのような局所散瞳薬 一毛様筋麻ひ(箄)薬を投与する。眼の熱傷の場合には, 眼科医に相談するべきである。

\section{$3 \cdot 4$ 要 約}

洗浄剤の誤飲・誤用暴露時の応急処置マネージメント に対する一般的アプローチは, 暴露の程度の診断, 暴露 物質の迅速な除去 (主に洗浄や希釈による) 及び注意深 い追跡調査を行って毒性症状や徴候を評価することであ る。暴露された製品に関する正確な情報とその毒性情報 を入手することが基本である。食道や胃に激しい熱傷を

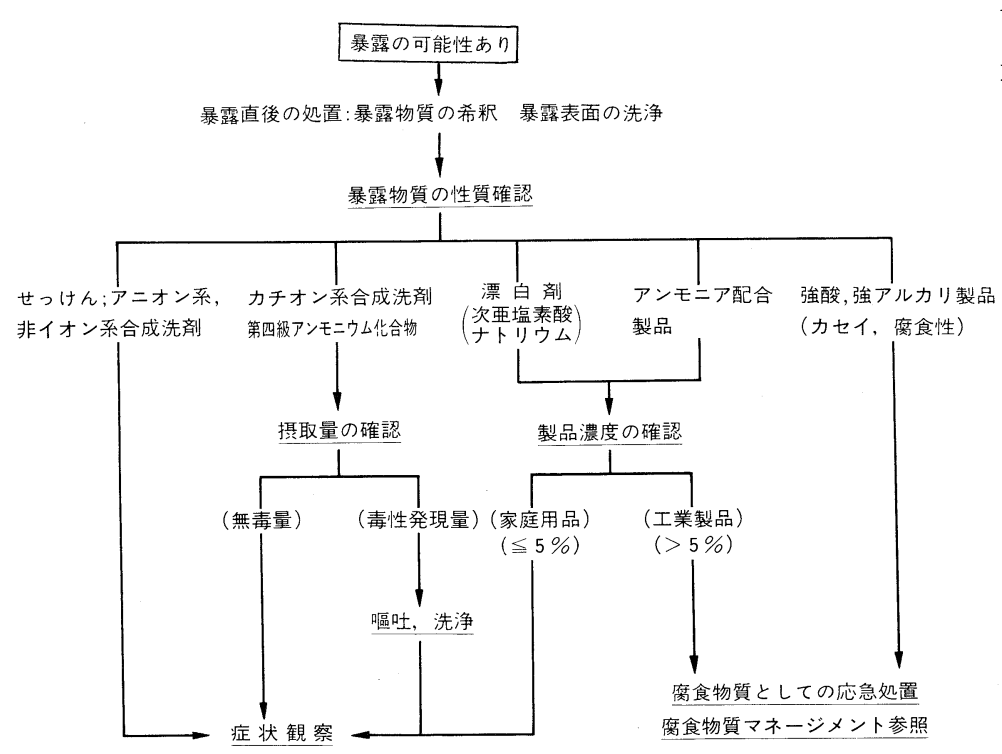

図-1家庭用洗浄剤の誤飲・誤用暴露時のマネージメント(応急処置)
起こす数種の製品に対しては, 診断や適切な応急処置を 行うために内視鏡検査を行う。家庭用洗浄剂の多くの暴 露事例では，重篤な毒性症状はほとんどないか，または 全く認められない。しかしながら，時に見られる重篤な 中毒事故に対しては, 注意深い応急処置を行うことによ り毒性症状の発現や合併症を最小限にすることが可能と なる。

\section{5 マネージメント (応急処置) のフロー図}

家庭用洗浄剂や腐食物質（アルカリ，酸）の誤飲・誤 用暴露に対する救急時の応急処置マネージメントの概略 を, 図 -1 , 図-2に紹介する。

\section{文献}

1) F.M. Henretig, G.C. Cupit, A.R. Temple, M. Collins, "Toxicologic Emergencies," Textbook of Pediatric Emergency Medicine, Second Edition, G. Fleisher, S. Ludwig, eds., Williams \& Wilkins, Baltimore (1988) p.548

2) A.R. Temple, "Bleach, Soaps and Detergents," Clinical Management of Poisoning and Drug Overdose, L.M. Haddad, J.F. Winchester, eds., W.B. Saunders Co., Philadelphia (1983) p.675

3) D. Tandberg, H.J. Liechty, D. Fishbein, Ann. Emerg. Med., 10, 521, (1973)

4) S. Locket, Practitioner, 210, 709 (1981)

5) O.J. Wolowodiuk, D.B. McMicken, P. O'Brien, Ann. Emerg. Med., 13, 1148 (1984)

6) W. Klein-Schwartz, R.L. Gorman, G. M. Oderda et al., Ann. Emerg. Med., 13, 1152 (1984)

7) A.H. Abdallah, A. Tye, Am. J. Dis. Child., 113, 571 (1967)

8) L. Boxer, F.P. Anderson, D.S. Rowe, $J$. Pediatr., 74, 800 (1969)

9) M. Burke, Resuscitation, 1, 91 (1972)

10) R. Okun, Clin. Toxicol., 6, 13 (1973)

11) E.F. Crain, L.C. Gershel, A.P. Mezey, Am. J. Dis. Child., 138, 863 (1984) 


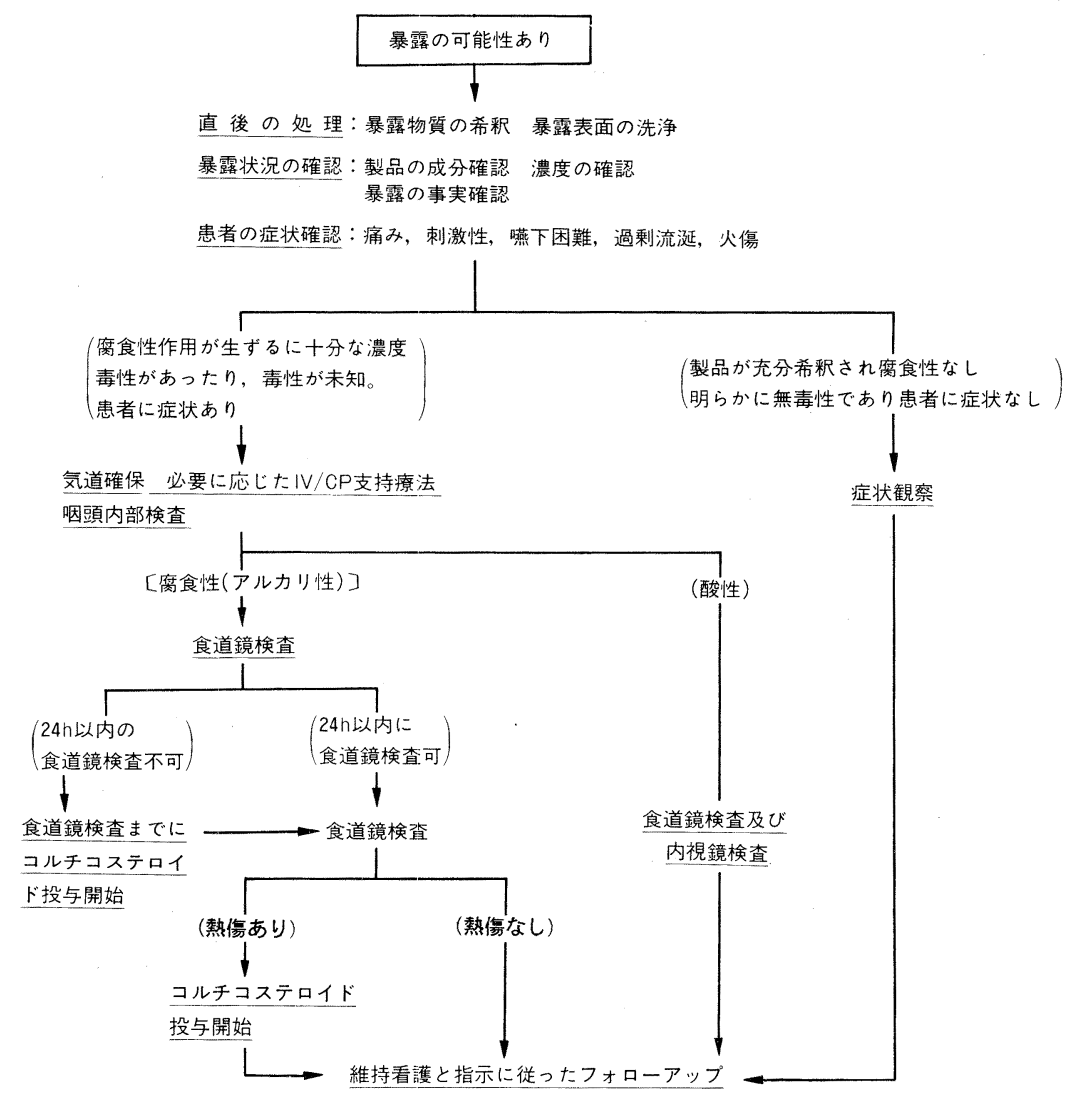

図-2 腐食物質（アルカリ，酸）の誤飲・誤用暴露時のマネージメント（応急処置）

\section{4 製品の種類別マネージメント}

\section{$4 \cdot 1$ 固形せっけん}

固形化粧せっけんは，一般にその毒性程度は低い。固 形化粧せっけんを誤飲した場合, 悪心, 嘔吐や下痢と共 に胃腸管刺激が認められる。応急処置は, 牛乳や水のよ うな保護剤や希棌剤を与えることである。胃の中を空に することは必ずしも必要でない。下浰や激しい嘔吐が起 こった場合, 対症療法及び体液と電解質のバランスを維 持するための処置を行う。せっけんの粉末, 泡もしくは 溶液が眼に誤って入った場合, 結膜炎や弱い刺激が生じ る。異物をすべて取り除くために少なくても $15 \mathrm{~min}$,

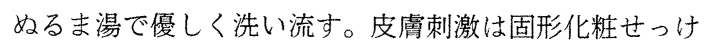
んが主要な原因とは考えられない。しかし, 感受性の高 い人の中には, 特別な固形せっけんを使用した後に皮虞 への影響を経験する人もいる。皮膚刺激が生じた時は, そのせっけんの使用を中止する。

洗濯用固形せっけ九は, 洗濯用合成洗剤が市販された ために現在は広範囲には使用されていない。この製品の 毒性は化粧せっけんと同程度であり, 暴露時は同様な処 置を行う。

\section{$4 \cdot 2$ 液体手洗いせっけん}

液体手洗いせっけんの誤飲・誤用時の応急処置法は, 固形せっけんと同様である。しかし, 液体手洗いせっけ んは簡単には洗い流せないこと, せっけんの泡の濃度が より高いことから, 眼に入った場合は問題となることが ある。ごくわずかな刺激であっても，充分な洗浄が必要 である。

\section{$4 \cdot 3$ シャンプー}

当初, すべてのシャンプーはせっけんから製造されて いたが, 現在では種々の界面活性剤（例えば，アニオン や非イオン）が広く使用されている。シャンプー製品に は液体, クリームもしくはジェルタイプがある。シャン プーの毒性は固形せっけんの毒性より若干高いが，一般 的にはその毒性の程度は低い。シャンプーを摂取した場 合胃に対する刺激によって，固形せっけん誤飲時に見ら れるよりも悪心や嘔吐が多く起きる。誤摂取時の応急処 置法は, 一般的には固形せっけんと同様に行う。ふけ防 止剂が配合されているシャンプーの場合は, 悪心や嘔吐 の発現が増える可能性はあるが, 応急処置法は普通の シャンプーと同様である。胃の中を空にする必要はない。 多くのシャンプーの原液は眼や粘膜に刺激を与える。 
眼や粘膜に接触した時は, すぐにシャンプーがすべて除

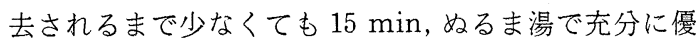
しく洗い流す必要がある。瞼の下もすすぐ。

\section{4 粒状洗濯用せっけん及び合成洗剂}

粒状洗濯用洗剂には，ア二オン界面活性剤及び洗剂用 ビルダーとしてリン酸塩, 炭酸塩及びアルミノシリケー 卜のような複合塩が一般的に配合されている。粒状洗濯 用洗片の多くは弱アルカリ性 $(\mathrm{pH}$ 10 11) であり, 酵

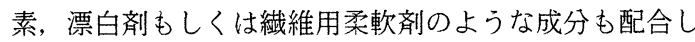
ている。これらの成分は，その製品の安全性に大きくは 影響を与えない。したがって，これら成分を配合した洗 剤の中毒症状と応急処置法は多くの粒状洗濯用洗剂之同 様である。

粒状洗濯用洗剂を誤摂取した場合, 少量でも数分以内 に嘔吐が起こるが, 重篤な中毒症状はめったに観察され ない。摂取後数時間から 2 日の間に下麻が現れる。暴露 を最低限にするために，3.2で述べたように水もしくは 牛乳で希釈する。嘔吐や下痢が激しい時は, 体液之電解 質のバランスを検査する。炭酸塩含有製品誤摂取時の応 急処置として酸性の解毒剂を投与することは, 熱や二酸 化炭素が発生し合併症を併発する可能性があるために, 禁忌である ${ }^{2) .31 。}$

多くの洗濯用洗剂は強アルカリ性ではないので, 胃や 食道の粘膜に対する損傷はみら机ない。しかし，この分 野の製品は比較的アルカリ度の高いものもあるので, 条 件によっては粘膜損傷を起こす。この可能性のある製品 に対しては, 包装に警告表示を付けることが法律で義務 づけられている。

すべての粒状洗濯用洗剂は, 表層性の一時的な眼刺激 を生じる。通常の症状は, 催淚, 結膜の発赤や感覚的な 刺激である ${ }^{4)}$ 。角膜上皮に表層性の損傷を与えることも ある。この影響は, 眼を擦ると更に悪化する。このよう な場合, 感覚刺激が継続する。刺激が $12 \mathrm{~h}$ 以上継続し た時は，医者の診断が必要である。

眼に入った場合, 残留物質を取り除くために，すぐに 眼瞼を開けたまま 15 min はぬるま湯で優しく洗い流さ なけ机ばいけない。コンタクトレンズを使用している場 合，できるだけ速やかにレンズをはずし上述のようにぬ るま湯で洗い流す。

粒状洗濯用洗剂の吸入暴露は, 通常は洗剂を注いでい る間に粉じんを誤って吸い込んだ場合であり，気道上部 に一時的な刺激が認められる。この上うな影響は, 数時 間以内に自然に正常に回復する。

粒状洗濯用洗剂の原末や水溶液に長時間接触した場 合, 発赤, かゆみや刺痛などの皮膚影響がみられる。こ れらの症状は, 寒く乾燥した季節や既に何らかの理由で 皮膚に傷がある場合に起こりやすい。皮膚を優しく洗っ て洗剤を除去したり，不快感を少なくするために冷湿布
をする。

\section{$4 \cdot 5$ 機械（自動）食器洗い機用合成洗剂}

食器洗い機用合成洗剤は, 現在, 粒状之液体の二種類 が市販されている。両者ともリン酸塩, 炭酸塩, ケイ酸 塩, 種々の界面活性剂及び塩素系漂白剂の混合物である。 液体の食器洗い機用合成洗剂は, 上述の成分の粘度の高 い水溶性䋰濁液である。液体と粒状製品共にアルカリ性 である。この分野の製品すべてには, 誤飲と眼刺激性に 対する警告表示が付けられている。

粒状または液体製品は, 例え少量䛊飲しても数分以内 に嘔吐が起こり, 暴露後数時間から 2 日までに下痢が始 まる。すぐに, 胃が膨張しない程度の水や牛乳で希釈す $ろ^{5)}$ 。嘔吐の誘発や胃洗浄は禁忌である ${ }^{6)}$ 。酸性の解毒 剤の使用もまた禁忌である ${ }^{2), 3(, 6) 。 ~}$

食器洗い機用合成洗剂の中には, アルカリ度が高いた めに粘膜に損傷を与える製品もある。これらの製品を摂 取した結果, 明らかな口腔内刺激が認められない場合で も，食道への重篤な刺激や食道狭窄が起こる可能性があ $3^{6)}$.7)。食道の損傷を調べるためには食道鏡検査を行 う。多量摂取したことが判明し, 激しい嘔吐や血液の混 じった嘔吐が見られた時は, すぐに応急処置を行う。重 篤な誤摂取事故の場合（血液の混じった嘔吐，激しい嘔 吐, 摂取量が多量之確認), 患者の検查には急性じん(腎) 毒性の項目も含めるべきである ${ }^{8)}$ 。

食器洗い機用合成洗剤はいずれも眼刺激がある。症状 之応急処置は, 既述の粒状洗濯用洗剤 $(4 \cdot 4)$ で述べた方 法と同様である。持続性もしくは激しい刺激が認められ た場合，眼科医の診断を受ける。

このタイプの製品には通常, 塩素系漂白剤が配合され ているので, その他の洗浄剤と混合してはならない。酸 性の洗浄剤之混合すると二酸化炭素や熱を放出したり, また塩素ガスを放出する可能性もある。アンモ二アもし くはアンモ二ア性界面活性剤を含有する手洗い用食器洗 い合成洗剂と混合すると, クロラミンガスが発生する。

これらのガスに暴露されると眼, 鼻や喉に一時的な刺激 之頭痛や息切れが時に見られる。暴露源から患者を移動 させれば，症状は急速に回復する。クロラミンガスに暴 露されると, 気道上部に刺激が見られるが, より激しい 影響はまれである。

濃縮製品が直接皮膚についたときには, 軽度から中程 度の皮膚刺激が見られる。一般には, 症状は発赤及び感 覚刺激である。液体製品の原液に接触した場合, 接触じ んましん (罸麻疹) がまれに発症する。これらの症状の 応急処置は, きれいな水で皮膚を優しく洗い流すこと, 不快感を取り除くために冷湿布をすること，更に刺激さ れないように影響部位を保護することである。

(次回に続く) 〔平成 2 年 $(1990$ 年) 10 月 3 日受理〕 